\title{
ASAS PACTA SUNT SERVANDA DALAM PENEGAKAN HUKUM PIDANA INTERNASIONAL*
}

\author{
Danel Aditia Situngkir \\ Program Studi D3 Bahasa Inggris, STBA Prayoga Padang \\ J1. Veteran No. 8 Padang \\ e-mail: danel@stba-prayoga.ac.id
}

\begin{abstract}
The dark history of the first world war and the second world war had an impact increasingly increasing international attention to the protection of human rights. One of the efforts made was strengthening the provisions in international law. The state as the main actor in international relations plays an important role in the establishment of norms in international law. In its development, state relations are regulated in international agreements. The most common principle in international treaties is pacta sunt servanda. In general, the pacta sunt servanda defined by the state is only bound by the agreement pursuant approval from the state. This becomes very crucial for the protection of the sovereignty of the state. In reality, however, there are few international treaties that grant rights and obligations to countries that do not participate in international treaties. Related to international criminal law enforcement, the existence of this principle keep on debated, especially since those stipulated in international criminal law are international crimes and punishment of perpetrators of such crimes. The international dimension in a crime can be seen from various aspects. Therefore this paper will discuss the principle of pacta sunt servanda in law enforcement of international criminal law. This research was normative juridical as the main approach. The principle of pacta sunt servanda should not be based of state bondage in international criminal law enforcement, the state may be bound in that by customary international law.
\end{abstract}

Keyword: Pacta Sunt Servanda, International Treaty, International Criminal Law

\begin{abstract}
Abstrak
Pengalaman buruk perang dunia pertama dan perang dunia kedua membawa dampak semakin meningkatkannya perhatian dunia internasional terhadap perlindungan hak asasi manusia. Salah satu upaya yang dilakukan adalah penguatan ketentuan dalam hukum internasional. Negara sebagai subjek utama dalam hubungan internasional yang memegang peran penting dalam pembentukan norma dalam hukum internasional. Dalam perkembangannya hubungan antar negara diatur dalam perjanjian internasional. Asas paling umum dalam perjanjian internasional adalah pacta sunt servanda. Secara umum pacta sunt servanda diartikan negara hanya terikat pada perjanjian berdasarkan persetujuan negara tersebut. Persetujuan ini menjadi sangat krusial demi perlindungan terhadap kedaulatan negara. Namun dalam realitasnya ditemukan perjanjian internasional yang memberikan hak dan kewajiban kepada negara-negara yang tidak mengikatkan diri dalam perjanjian internasional. Jika dikaitkan dengan penegakan hukum pidana internasional keberadaan asas ini terus mengalami perdebatan, terlebih karena yang diatur dalam hukum pidana internasional adalah kejahatan internasional dan hukuman terhadap pelaku dari kejahatan tersebut. Dimensi internasional dalam suatu kejahatan dapat dilihat dari berbagai aspek. Maka dari itu tulisan ini akan membahas asas pacta sunt servanda dalam penegakan hukum pidana internasional. Penelitian ini bersifat yuridis normatif sebagai pendekatan utama. Asas pacta sunt servanda tidak harus menjadi dasar terikatnya negara dalam penegakan hukum pidana internasional, negara bisa terikat berdasarkan hukum kebiasaan internasional.
\end{abstract}

Kata kunci: Pacta Sunt Servanda, Perjanjian Internasional, Hukum Pidana Internasional

\footnotetext{
* Naskah diterima: 27 Februari 2018, direvisi:1 Maret 2018, disetujui untuk terbit: 06 Maret 2018
} 


\section{PENDAHULUAN}

Semakin menguatnya perhatian dunia internasional tentang perlindungan hak asasi manusia telah memberikan warna baru bagi hukum internasional, khususnya hukum pidana internasional. Pengalaman buruk dari Perang Dunia II yang berlangsung dari tahun 1939-1945 dan perang asia timur raya (bagian dari Perang Dunia II) yang berlangsung dari tahun 1942-1945 telah menimbulkan korban luar biasa banyak, baik berupa korban manusia, harta benda, baik di pihak pemenang perang maupun pihak yang kalah perang. Setelah perang berakhir muncul ide untuk meminta pertanggungjawaban secara langsung kepada individu yang dituduh melakukan pelanggaran hukum internasional dengan mengajukannya kehadapan pengadilan internasional.

Hal ini membuat sematan "quacy of law" bagi hukum pidana internasional mulai memudar seiring dengan makin kuatnya kesepahaman atas prinsip non impunitas (tidak ada kekebalan) bagi para pelaku kejahatan luar biasa terhadap kemanusiaan. Namun hal tersebut masih menyisakan permasalahan karena melibatkan peran negara sebagai pemeran utama dalam hubungan internasional. Permasalahan paling mendasar dari upaya tersebut adalah aspek terpenting dalam negara yakni kedaulatan.

Dimana dalam hukum internasional dikenal prinsip persamaan kedudukan negara. Keberadaan piranti hukum pidana internasional ini menjadi polemik dimana setiap negara memiliki kedaulatan sendiri- sendiri terhadap orang, benda dan peristiwa yang terjadi di dalam negara tersebut. Layaknya hukum internasional yang dibentuk berdasarkan konsensus, hukum pidana internasionalpun demikian. Konsekuensi logis dari sebuah konsensus adalah negara boleh ikut dan boleh tidak. Dalam prinsip umum hukum internasional dikenal asas pacta sunt servanda yang secara umum dapat diartikan perjanjian itu hanya mengikat pihak-pihak yang membuatnya. Melihat ini tentunya ada potensi hukum pidana internasional kembali pada posisi quacy of law. Maka dari itu penulis merasa tertarik membahas tentang Asas Pacta Sunt Servanda dalam Penegakan Hukum Pidana Internasional.

\section{METODE PENELITIAN}

Kajian penelitian ini bersifat yuridis normatif sebagai pendekatan utama, dengan melihat hukum internasional sebagai kaidah/norma dan prinsip-prinsip hukum umum dalam penegakan hukum pidana internasional. Peneliti akan mendasarkan pada ketentuan dan prinsipprinsip umum dalam hukum perjanjian internasional dan hukum pidana internasional. Pada penelitian yuridis normatif, jenis data yang dipergunakan adalah data sekunder, yang diperoleh dari data kepustakaan (Marzuki, 2005, hal. 24).

Metode pengumpulan data yang digunakan dalam penelitian ini adalah dengan studi dokumen. analisis data tidak dapat dilepaskan dari berbagai penafsiran. (Amiruddin, 2012, hal. 163) Penafsiran yang dipergunakan dalam penulisan ini adalah penafsiran sejarah yaitu dengan 
Danel Aditia Situngkir: Asas Pacta Sunt Servanda Dalam Penegakan Hukum Pidana...

menelaah sejarah hukum atau menelaah pembuatan suatu ketentuan yang diatur dalam perjanjian internasional khususnya yang berkaitan dengan pidana internasional.

\section{HASIL DAN PEMBAHASAN}

\section{Asas Pacta Sunt Servanda Dalam Perjanjian Internasional}

Dilihat dari sejarah, hubungan internasional antar bangsa-bangsa di dunia hanya diatur berdasarkan kebiasaan-kebiasaan internasional yang dianggap benar dan dilakukan terus menerus. Dalam beberapa dekade terakhir meningkatnya intensitas hubungan internasional berujung pada timbulnya kesadaran masyarakat internasional bahwa kebiasaan yang dipergunakan selama ini dalam hubungan internasional tidak dapat dipergunakan sebagai acuan menyelesaikan berbagai permasalahan yang timbul. Maka dari itu semakin dirasakan pentingnya suatu norma yang mengatur bagaimana hubungan dalam masyarakat internasional dalam bentuk perjanjian internasional.

Dalam perkembangannya norma yang mengatur hubungan masyarakat internasional tersebut diatur dalam berbagai perjanjian internasional. Terikatnya negara dalam perjanjian internasional bergantung kepada kebutuhan dari negara tersebut. Secara fungsional perjanjian internasional dilihat dari sumber hukum, maka perjanjian internasional dibedakan dalam dua golongan, yaitu: treaty contracts dan law making treaties. Treaty contract adalah perjanjian seperti suatu kontrak atau perjanjian dalam hukum perdata yang mengakibatkan hak dan kewajiban antara pihak-pihak yang mengadakan perjanjian itu saja, contoh perjanjian perbatasan dan perjanjian perdagangan. Law making treaties adalah perjanjian internasional yang meletakkan ketentuan-ketentuan atau kaidah-kaidah hukum bagi masyarakat internasional secara keseluruhan, misalnya Konvensi Wina 1969 tentang Hukum Perjanjian Internasional dan Konvensi Hukum Laut 1982. (Ardhiwisastra, 2003, hal. 107-108).

John O'Brian merangkum beberapa prinsip yang menjadi dasar dari traktat atau perjanjian internasional mengikat bagi negara ketiga: (Iskandar, 2009, hal. 56-57).

1. Muncul diakibatkan persetujuan.

2. Negara yang memberikan persetujuan untuk memberlakukannya sebagaimana yang diinginkan oleh traktat terhadap pihak lain.

3. Dalam hal traktat (perjanjian) tersebut mengkodifikasi kebiasaan, maka Negara-negara peserta terikat oleh traktat yang menurut prinsipprinsip umum.

4. Dalam hal bukan Negara peserta, maka traktat tetap mengikat berdasar pada alasan kewajiban muncul sebagai akibat dari kebiasaan.

5. Traktat multilateral pada umumnya dibentuk dibawah International Law Commision, yang tujuan untuk terciptanya pembentukan hukum internasional yang progresif, yang tentunya melibatkan kodifikasi atas hukum kebiasaan.

Asas Pacta Sunt Servanda merupakan salah satu prinsip hukum 
umum yang diakui oleh negara-negara beradab di dunia dalam kerangka hubungan internasional. Prinsip ini diakui universal. Schmitthof dan juga Goldstajn menganggap prinsip/asas ini (beserta prinsip kebebasan berkontrak) sebagai prinsip yang penting. Pengakuan dalam sistim hukum di dunia tidak terlalu sulit untuk menemukannya. Bahkan negaranegara di dunia memasukkan ketentuan ini dalam peraturan perundangan nasionalnya. (Adolf, 2006, hal. 25-26).

Secara umum pacta sunt servanda diartikan sebagai terikatnya suatu negara terhadap suatu perjanjian internasional diakibatkan oleh persetujuan dari negara tersebut untuk mengikatkan diri pada perjanjian internasional. Ketika suatu Negara menjadi pihak dalam perjanjian internasional, menyatakan kehendak untuk terikat terhadap ketentuan yang diatur dalam perjanjian tersebut. Hal itu berdampak ketentuan-ketentuan yang diatur dalam perjanjian itu berlaku dalam teritorial negara yang menyatakannya.

Asas pacta sunt servanda merupakan salah satu norma dasar dalam hukum perjanjian, dan erat kaitannya dengan asas itikad baik untuk menghormati atau mentaati ketentuan dalam perjanjian. Hugo de Groot atau yang lebih dikenal dengan Grotius mengatakan bahwa diantara asas-asas hukum alam yang melandasi sistem hukum internasional, pacta sunt servanda merupakan asas paling fundamental. Pacta sunt servanda yang merupakan bagian dari hukum kodrat yang menjadi dasar bagi konsensus. Anzilotti penganut aliran dualisme berkebangsaan Italia menguatkan pandangan Grotius dan meletakan dasar daya ikat hukum internasional pada asas pacta sunt servanda. (Ardhiwisastra, 2003, hal. 72).

Terikatnya satu negara dalam perjanjian internasional dilihat dari 2 (dua) perspektif. Perspektif yang pertama yaitu tindakan yang dilakukan negara sendiri dalam suatu perjanjian internasional. Negara dikatakan terikat pada perjanjian internasional apabila melakukan tindakan Penandatanganan (Signatured) (Convention, 1969, hal. Art. 12 (1)), Pertukaran instrument-instrument (exchange of instruments constituting a treaty), (Convention, 1969, hal. Art. 13) Ratification, acceptance or approval. (Convention, 1969, hal. Art.14) Apabila negara melakukan tindakan-tindakan diatas maka negara terikat pada ketentuan hukum dalam perjanjian internasional itu sendiri.

Perspektif yang kedua adalah dilihat dari substansi atau norma yang diatur dalam perjanjian internasional itu sendiri. Sejatinya jika perjanjian dibuat maka yang terikat hanya pihak-pihak yang terlibat dalam perjanjian internasional itu sendiri. Dalam perjanjian internasional istilah pihak sering disebut "Parties" atau "State Parties". Namun tidak jarang perjanjian internasional juga memberikan hak kepada negara ketiga atau negara lain yang bukan pihak dalam perjanjian internasional tersebut. Frasa yang sering dipakai untuk negara bukan pihak perjanjian internasional tersebut misalnya 
Danel Aditia Situngkir: Asas Pacta Sunt Servanda Dalam Penegakan Hukum Pidana...

"Every State" atau "Non State Parties" atau "All State".

Beberapa contoh perjanjian international yang memberikan hak atau kewajiban kepada negara bukan pihak diantaranya:

1. Piagam Perserikatan Bangsa-Bangsa (Nations, Charter of The United Nations, 1945)

Pasal 6 ayat 1 dikatakan negaranegara bukan anggota Perserikatan Bangsa-Bangsa bertindak dengan prinsip-prinsip ini apabila dianggap perlu demi perdamaian internasional.

2. Deklarasi Universal Hak-Hak Asasi Manusia (Nations, Universal Declaration of Human Rights)

Dalam deklarasi yang diterima dan diumumkan oleh Majelis Umum PBB pada tanggal 10 Desember 1948 melalui resolusi 217 A (III) ini frasa yang dipakai adalah setiap orang. Dengan demikian ini dapat dimaknai sebagai setiap orang yang merupakan warga negara pada negara peserta maupun negara bukan peserta dalam deklarasi tersebut maupun piagam $\mathrm{PBB}$, karena deklarasi ini dipelopori oleh PBB.

3. Konvensi Jenewa tahun 1949 tentang perbaikan keadaan anggota angkatan perang yang luka dan sakit di medan pertempuran darat. (The Geneva Conventions of 12 August 1949, 1949)

Dalam pasal 2 konvensi ini diatur meskipun salah satu dari Negaranegara dalam pertikaian mungkin bukan peserta Konvensi ini, Negaranegara yang menjadi peserta Konvensi ini akan sama tetap terikat olehnya di dalam hubungan antara mereka. Mereka selanjutnya terikat oleh Konvensi ini dalam hubungan dengan Negara bukan peserta, apabila Negara yang tersebut kemudian ini menerima dan melaksanakan ketentuan-ketentuan Konvensi ini.

4. Konvensi Hukum Laut

Dalam konvensi hukum laut 1982 dipakai frasa "every state" ini diartikan setiap negara, bisa negara yang menjadi pihak dalam perjanjian international tersebut maupun negara yang bukan menjadi pihak. Beberapa hak dan kewajiban negara ketiga yang diberikan dalam konvensi hukum laut diantaranya:

a. Hak untuk menetapkan lebar laut teritorial 12 mil laut.

b. Hak untuk melayarkan kapal dibawah benderanya di laut lepas.

c. Pemberian kebangsaannya pada kapal, untuk pendaftaran kapal di dalam wilayah, dan untuk hak mengibarkan benderanya.

d. Mewajibkan nakhoda kapal yang berlayar dibawah benderanya untuk, selama hal itu dapat dilakukannya tanpa bahaya yang besar bagi kapal, awak kapal atau penumpang untuk memberikan pertolongan di laut.

e. Menyita suatu kapal atau pesawat udara perompak atau suatu kapal atau pesawat udara yang telah diambil oleh perompak dan berada di bawah pengendalian perompak dan menangkap orang-orang yang menyita barang yang ada di kapal

f. Melakukan penindakan terhadap yang dicurigai suatu kapal yang mengibarkan benderanya terlibat dalam perdagangan gelap obat narkotik atau bahan psikotropis 
dapat meminta kerja sama Negara lain untuk menumpas perdagangan demikian.

g. Menuntut orang yang melakukan penyiaran gelap dapat dituntut di muka pengadilan.

h. Mengambil tindakan efektif untuk mencegah dan menghukum pengangkutan budak belian dalam kapal.

i. Menetapkan peraturan perundang undangan yang diperlukan untuk mengatur bahwa pemutusan atau kerusakan pada kabel bawah laut di bawah laut lepas yang dilakukan dengan sengaja atau karena kelalaian.

j. Menetapkan peraturan perundangundangan yang diperlukan untuk menjamin bahwa pemilik kapal yang dapat membuktikan bahwa mereka telah mengorbankan sebuah jangkar, sebuah jaring atau peralatan penangkapan ikan lainnya dalam usaha untuk mencegah terjadinya kerusakan pada kabel atau pipa bawah laut, harus diberi ganti kerugian oleh pemilik dari kabel atau pipa tersebut, dengan ketentuan bahwa pemilik kabel itu telah mengambil segala tindakan pencegahan yang wajar sebelumnya.

k. Memperhatikan seperlunya hakhak dan kepentingan-kepentingan sah setiap Negara pantai yang yurisdiksinya dilintasi endapanendapan tersebut.

Ketentuan yang mengatur mengenai negara bukan peserta dalam perjanjian internasional dapat dilihat pada pasal 34 sampai 38 Konvensi Wina 1969. Dalam pasal 34 disebutkan: "a treaty does not create either obligations or rights for a third State without its consent" Prinsip utama yang dikodifikasikan dalam pasal 34 Konvensi Wina 1969 adalah bahwa perjanjian tidak menciptakan baik kewajiban atau hak untuk sebuah negara ketiga tanpa persetujuan.

Konvensi memisahkan pengaturan antara kewajiban (pasal 35) dan hak (pasal 36) Negara ketiga dalam perjanjian internasional. Dalam pasal 37 khusus mengatur mengenai pencabutan atau modifikasi kewajiban atau hak dari Negara ketiga.

Beberapa penulis mengungkapkan meskipun dalam pasal 34 diatur prinsip utama sebagaimana disebutkan diatas, namun terdapat regulasi pemberian hak dan pemenuhan kewajiban-kewajiban berdasarkan persetujuan Negara ketiga

Sebagaimana diatur dalam pasal 36 tentang aturan umum pada prinsip persetujuan. Hal ini membedakan bentuk persetujuan ini. Ketentuan "... unless the treaty otherwise provides ", berarti bahwa jika perjanjian itu menyatakan bahwa negara harus menyatakan persetujuannya dalam bentuk tertentu, efek hukum hanya akan timbul jika kondisi ini telah terpenuhi.

Ketika perjanjian ini tidak mengatur hal tersebut, persetujuan dapat dianggap tidak memiliki dampak bagi Negara ketiga. (Fitzmaurice, 2002, hal. 44-45) Sementara dalam pasal 38 Konvensi Wina 1969 disebutkan: "Nothing in articles 34 to 37 precludes a rule set forth in a treaty 
Danel Aditia Situngkir: Asas Pacta Sunt Servanda Dalam Penegakan Hukum Pidana...

from becoming binding upon a third State as a customary rule of international law, recognized as such". Pasal 38 berkaitan dengan situasi ketika perjanjian menjadi mengikat negara ketiga melalui hukum kebiasaan internasional.

Dengan demikian dapat disimpulkan, dalam kasus kewajiban yang timbul dari perjanjian, tiga kondisi yang harus dipenuhi: (Fitzmaurice, 2002, hal. 57).

1. Dengan persetujuan negara bukan peserta, yang mengungkapkan pengakuan terhadap kewajiban yang diberikan oleh perjanjian.

2. Bentuk tertulis dari suatu persetujuan. pasal 34-37 (pasal 37 termasuk dalam kategori yang sama seperti pasal 3536, karena menyangkut yaitu pencabutan atau modifikasi kewajiban atau hak-hak negara ketiga, atau organisasi yang timbul berdasarkan pasal 35 dan 36) Pihak dalam perjanjian mengungkapkan keinginan mereka untuk menciptakan baik hak atau kewajiban negara (atau organisasi) yang bukan merupakan pihak dalam perjanjian.

3. Ketika perjanjian menjadi mengikat negara-negara ketiga melalui mekanisme hukum kebiasaan internasional sesuai dengan pasal 38.

\section{Asas Pacta Sunt Servanda Dalam Penegakan Hukum Pidana Internasional}

Istilah Hukum Pidana Internasional atau International Criminal Law atau Internationale Strafprocessrecht semula diperkenalkan dan dikembangkan oleh pakar-pakar hukum internasional dari Eropa daratan seperti: Friederich Meili pada tahun 1910 (Swiss); Georg Schwarzenberger pada tahun 1950 (Jerman); Gerhard Mueller pada tahun 1965 (Jerman); J.P. Francois pada tahun 1967; Roling pada tahun 1979 (Belanda); Van Bemmelen pada tahun 1979 (Belanda); kemudian diikuti oleh pakar hukum dari Amerika Serikat seperti: Edmund Wise pada tahun 1965 dan Cherif Basiouni pada tahun 1986. (Atmasasmita, 2006, hal. 19).

Secara ringkas hukum pidana internasional dapat didefinisikan sebagai sekumpulan kaidah-kaidah dan asas hukum yang mengatur tentang kejahatan internasional. (Parthiana, 2006, hal. 26) Untuk lebih mempertegas hal tersebut, dikatakan kaidah-kaidah atau asas hukum berarti menyangkut tentang substansi norma yang diatur dalam suatu perjanjian internasional. Yang mana norma tersebut tentang klasifikasi dari perbuatan yang termasuk kedalam kejahatan internasional, siapa yang harus bertanggungjawab terhadap perbuatan tersebut, siapa yang berhak melakukan penuntutan dan siapa yang berhak mengadili dan seterusnya. Semua hal tersebut diatur dalam suatu perjanjian internasional.

Karena semua ketentuan tersebut dimuat dalam perjanjian internasional, maka pihak-pihak yang terlibat dalam proses pembentukan dari perjanjian tersebut adalah negara. Jean Bodin menganggap kedaulatan sebagai ciri khusus dari Negara, kedaulatan merupakan hal yang pokok dari setiap kesatuan berdaulat yang disebut Negara. 
(Ardhwisastra, 1999, hal. 41) Tanpa kedaulatan, maka tidak ada Negara dan karenanya kedaulatan merupakan kekuasaan mutlak dan abadi dari negara yang tidak terbatas dan tidak dapat dibagibagi.

Kedaulatan sebagai kekuasaan tertinggi dimiliki oleh Negara, memang menimbulkan kesan bertentangan dengan hukum internasional, dimana hukum internasional sebagai suatu sistem yang mengatur hubungan antar Negara. Hukum internasional tidak mungkin mengikat apabila Negara-negara tidak mengakui adanya suatu kekuasaan lain yang lebih tinggi lagi di atasnya. Paham kedaulatan absolutisme yang demikian akan menghambat perkembangan masyarakat internasional dan perkembangan hukum internasional itu sendiri.

Dalam hukum pidana internasional sebenarnya baru pada saat diberlakukannya Statuta Roma ada norma yang secara positif dapat diberlakukan dalam penegakan hukum pidana internasional. Usaha penegakan hukum pidana internasional sebelumnya untuk meminta pertanggungjawaban pada pelaku sebenarnya bertentangan dengan asas non retroakif. Pada beberapa pengadilan pidana internasional yang sebelumnya dibentuk, selain bersifat $a d$ hoc juga dibentuk berdasarkan pada perjanjian yang dibuat setelah peristiwa terjadi. Pengadilan Pidana Internasional yang sebelumnya yaitu:

1. Nuremberg Tribunal (Mahkamah Militer Internasional Nuremberg) (1949, hal. 8-9).
Amerika Serikat, Prancis, Inggris dan Republik Uni Soviet menandatangani London Agreement pada tanggal 8 Agustus 1945 untuk mendirikan Mahkamah Militer Internasional. Mahkamah ini dibentuk untuk mengadili penjahat/orang-orang yang bertindak dalam kepentingan European Axis Countries, baik sebagai individu atau sebagai anggota organisasi, yang melakukan kejahatan terhadap perdamaian, kejahatan perang, kejahatan terhadap kemanusiaan.

2. Tokyo Tribunal (Makhamah Militer Internasional Tokyo) (International Military Tribunal For The Far East, 1948).

Jenderal MacArthur bertindak dengan kewenangan sebagai panglima tertinggi sekutu pada tanggal 19 Januari 1946 mendirikan Mahkamah untuk mengadili orang-orang secara individu atau sebagai anggota organisasi atau keduanya yang melakukan kejahatan terhadap perdamaian. Mahkamah Internasional untuk Timur Jauh ini dibentuk untuk menghukum dengan menyelenggarakan persidangan yang adil dan cepat para penjahat perang besar di timur jauh Mahkamah Internasional ini memiliki yuridiksi mengadili dan menghukum penjahat perang Timur Jauh sebagai individu atau sebagai anggota organisasi yang didakwa dengan pelanggaran yang meliputi Kejahatan terhadap Perdamaian Konvensional Kejahatan Perang Kejahatan Terhadap Kemanusiaan. 
Danel Aditia Situngkir: Asas Pacta Sunt Servanda Dalam Penegakan Hukum Pidana...

3. International Criminal Tribunal for the Former Yugoslavial ICTY (Mahkamah Kejahatan Perang dalam Kasus bekas Yugoslavia) (Statute of The International Criminal Tribunal For The Former Yugoslavia, 1993).

Mahkamah ini didirikan berdasarkan Resolusi Dewan Keamanan PBB yang bertindak berdasarkan Bab VII Piagam PBB, Mahkamah dibentuk untuk menuntut orang bertanggung jawab terhadap pelanggaran berat hukum humaniter internasional di wilayah bekas Yugoslavia sejak tahun 1991. Mahkamah memiliki yurisdiksi untuk mengadili orangorang yang bertanggung jawab atas pelanggaran serius terhadap hukum humaniter internasional (pelanggaran berat Konvensi Jenewa 12 Agustus 1949, Pelanggaran hukum atau kebiasaan perang, genosida, Kejahatan terhadap kemanusiaan).

4. International Criminal Tribunal for Rwandal ICTR (Mahkamah Kejahatan Perang dalam Kasus bekas Rwanda) (Statute Of The International Tribunal For Rwanda, 1994).

Mahkamah ini didirikan berdasarkan Resolusi Dewan Keamanan PBB yang bertindak berdasarkan Bab VII Piagam PBB untuk menuntut Orang Bertanggung jawab terhadap kejahatan genosida dan pelanggaran serius hukum humaniter internasional lain di Wilayah Rwanda dan Negara tetangga, yang terjadi antara 1 Januari 1994 sampai 31 Desember 1994 Mahkamah Internasional memiliki yurisdiksi mengadili orang-orang yang bertanggung jawab atas pelanggaran serius terhadap hukum humaniter internasional (genosida, kejahatan terhadap kemanusiaan, Pelanggaran Pasal Umum 3 Konvensi Jenewa dan Protokol Tambahan II).

Melihat pengadilan pidana internasional ad hoc diatas bisa dilihat bahwa pembentukan perjanjian yang menjadi dasar pembentukan mahkamah terjadi setelah peristiwa terjadi dan diberlakukan surut. Pembentukan nurenberg tribunal dan tokyo tribunal cenderung lebih kepada keinginan negara pemenang perang untuk menghukum negara yang kalah dalam perang dunia kedua. Kiranya istilah "history written by the winner" tidak terlalu mengada-ada jika disematkan pada peristiwa ini. Karena orang-orang yang diadili pada pengadilan tersebut merupakan warga Negara dari Negara yang kalah dalam perang dunia kedua yang tidak mungkin menolak keinginan Negara pemenang perang untuk mengadili orang yang dianggap "pelaku" melalui London Agreement dan International Military Tribunal for Far East Charter. Bahkan dalam pembentukan dua perjanjian tersebut negara-negara yang warga negaranya diadili tidak menyatakan persetujuan untuk tunduk pada ketentuan di dalamnya, meskipun ketentuan ketentuan dalam perjanjian tersebut bertalian dengan kepentingan negaranegara tersebut.

Sementara pada peristiwa Rwanda merupakan negara pihak dengan meratifikasi konvensi ini pada tahun 1964. Artinya pemberlakuan yurisdiksi 
pengadilan tersebut untuk peristiwa yang terjadi di rwanda merupakan konsekuensi dari pengikatan diri terhadap ketentuan dalam Statute of The International Tribunal For Rwanda (ICRC, 1964) untuk peristiwa yang terjadi di negara Yugoslavia yang bukan merupakan negara yang menjadi pihak dalam konvensi jenewa ini, namun dasar pendiriannya adalah peristiwa yang terjadi di daerah yugoslavia tersebut merupakan kejahatan internasional dan Dewan keamanan PBB bertindak berdasarkan bab VII piagam $\mathrm{PBB}$.

Setelah pembentukan 4 (empat) pengadilan ad hoc yang diwarnai dengan perdebatan dikalangan akademisi terkait dengan prinsip-prinsip umum yang dilanggar seperti pacta sunt servanda, retroaktif dan legalitas maka pada tahun 1998 dibentuklah Statuta Roma tentang pendirian Mahkamah Pidana Internasional. Statuta ini dinyatakan berlaku setelah 60 (enam puluh) negara menyerahkan dokumen ratifikasinya kepada Majelis Umum PBB. Mahkamah ini merupakan terobosan baru dalam penegakan hukum pidana internasional karena Mahkamah ini merupakan pengadilan pidana internasional yang permanen pertama yang didirikan.

Mahkamah Pidana internasional ini tentunya hanya mengadili kejahatankejahatan tertentu saja. Bicara tentang kejahatan internasional tentulah kejahatan yang sangat serius terhadap kemanusiaan. Dalam Statuta Roma disebutkan 4 (empat) kejahatan yang menjadi yurisdiksi dari mahkamah yaitu kejahatan genosida, kejahatan terhadap kemanusiaan, kejahatan perang, kejahatan agresi. (Statute, 1998, hal. Art.5). Dalam Pasal 17 Statuta Roma merupakan norma sentral dalam konsep komplementaris dari Mahkamah Pidana Internasional. Ini menetapkan kriteria sebelum diterimanya suatu kasus oleh Mahkamah Pidana Internasional, Jaksa dan Hakim Mahkamah Pidana Internasional akan mengevaluasi kasus tersebut terlebih dahulu.

Pemberlakuan yurisdiksi Mahkamah Pidana Internasional hanya dapat menggantikan yurisdiksi pengadilan nasional jika pengadilan nasional telah memenuhi kriteria prinsip admissibility. Prinsip admissibility ini harus memenuhi 2 (dua) kriteria yaitu:

\section{Ketidak Inginan ( unwillingnes)}

Ketidak inginan suatu Negara mengadili suatu kejahatan yang merupakan yurisdiksi Mahkamah Pidana Internasional yang terjadi di wilayah teritorialnya berakibat Mahkamah Pidana Internasional akan campur tangan dalam kasus di mana Mahkamah Pidana Internasional ditemukan tindakan domestik digunakan secara nyata tidak untuk menegakkan keadilan.

Indikator yang dapat digunakan untuk melihat ketidak inginan yang sungguhsungguh dari pengadilan nasional tempat terjadinya suatu kejahatan yang diatur dalam statuta yaitu: (Statute, 1998, hal. Art.17).

a. Peradilan dilaksanakan dengan maksud untuk melindungi seseorang 
Danel Aditia Situngkir: Asas Pacta Sunt Servanda Dalam Penegakan Hukum Pidana...

dari pertanggungjawaban pidana atas kejahatan yang telah dilakukannya.

b. Proses peradilan ditunda-tunda tanpa ada alasan yang dapat dipertanggungjawabkan sehingga bertentangan dengan maksud dan tujuan diajukannya seseorang ke hadapan pengadilan.

c. Proses peradilan tidak dilaksanakan secara bebas dan independen.

2. Ketidakmampuan (inability)

Statuta mengidentifikasi 3 (tiga) keadaan untuk menyatakan ketidakmampuan Negara tersebut, yaitu: (Benzing, 2003, hal. 613).

a. Negara tidak dapat memperoleh terdakwa.

b. Negara tidak dapat memperoleh bukti yang diperlukan dan kesaksian untuk menempatkan orang-orang yang diduga bertanggung jawab untuk diadili.

c. Negara tidak mampu melaksanakan proses peradilan.

Runtuhnya sistem peradilan suatu negara dapat di asumsikan dimana otoritas negara telah kehilangan kontrol kekuasaannya dalam hal melaksanakan administrasi peradilan atau dimana pihak berwenang, tidak dapat melaksanakan kewenangan sebagaimana mestinya.

Keterikatan Negara bukan peserta terhadap yurisdiksi Mahkamah Pidana Internasional disebabkan kejahatan yang menjadi yurisdiksi Mahkamah Pidana Internasional merupakan international crimes. Statuta Roma merupakan perjanjian bersifat universal yang memiliki tujuan untuk membentuk norma dalam hukum internasional dan kejahatan yang diatur berasal dari hukum kebiasaan internasional. Mahkamah Pidana Internasional dapat memberlakukan yurisdiksinya dengan mekanisme pasal 13 ayat b Statuta Roma yakni ketika Dewan Keamanan PBB mengajukan suatu situasi kepada Jaksa Mahkamah dengan bertindak berdasarkan BAB VII Piagam PBB. Mahkamah Pidana Internasional baru dapat memberlakukan yurisdiksinya ketika Negara bukan peserta terbukti tidak ingin atau tidak mampu untuk menuntut, mengadili secara efektif pelaku kejahatan tersebut. (Situngkir, 2013)

Dari penjabaran diatas dapat dilihat bahwa keberadaan asas pacta sunt servanda dalam penegakan hukum pidana internasional semakin menguat dari waktu ke waktu. Ini dilihat dengan semakin sulitnya kriteria yang diberikan untuk memberlakukan ketentuan dalam perjanjian yang berkaitan dengan pidana internasional kepada negara yang tidak mengikatkan diri dalam perjanjian internasional tersebut. Artinya persamaan kedaulatan negara semakin bisa dirasakan. Karakteristik pidana internasional ini yang tidak jauh berbeda dengan pidana nasional dimana yang diminta pertanggung jawabannya adalah individu semakin erat kaitannya dengan kedaulatan negara, karena seharusnya negara tersebut yang memiliki kewenangan untuk mengadili warga negaranya.

Namun asas pacta sunt servanda ini tidak mutlak seperti yang didefinisikan secara umum. Tetap diberikan ruang bagi 
pihak lain untuk melakukan upaya yang perlu untuk meminta pertanggungjawaban pelaku kejahatan internasional tersebut. Semua ini dilakukan untuk memberikan efek jera bagi para pelaku serta mencegah kejahatan yang sama terjadi di tempat yang lain. Mekanisme yang lazim dipergunakan bagi negara-negara yang tidak menjadi pihak adalah atas rekomendasi atau penilaian dari Dewan Keamanan PBB yang bertindak berdasarkan Piagam PBB terhadap suatu peristiwa yang terjadi di dalam suatu negara.

\section{SIMPULAN}

Asas Pacta Sunt Servanda dalam perjanjian internasional merupakan prinsip umum yang diakui oleh negaranegara. Keberadaan asas ini memberikan kebebasan kepada negara untuk mengikatkan diri atau tidak dalam perjanjian internasional. Kebebasan ini menjadi penting karena negara memiliki kedaulatan masing-masing. Terikatnya suatu negara dalam perjanjian internasional dalam dilihat dari 2 (dua) perspektif. Pertama dari tindakan negara, dengan Penandatanganan, Pertukaran instrument-instrument dan Ratification, acceptance or approval. Perspektif yang kedua adalah dilihat dari substansi atau norma yang diatur dalam perjanjian internasional itu sendiri. Ada kalanya perjanjian internasional memberikan hak dan kewajiban bagi negara ketiga (bukan negara pihak dalam perjanjian internasional). Perjanjian internasional itu biasanya tergolong kepada perjanjian yang berisi ketentuan yang berasal dari hukum kebiasaan internasional.

Dalam Penegakan Hukum Pidana Internasional asas pacta sunt servanda juga semakin menguat seiring dengan perkembangan zaman. Dengan melihat secara pembentukan pengadilan pidana internasional ad hoc sebelumnya dapat kita simpulkan, bahwa pengakuan terhadap kedaulatan negara dengan diperkuatnya asas pacta sunt servanda ini semakin nyata. Namun karena tujuan dari pidana internasional ini adalah meminta pertanggungjawaban pelaku kejahatan internasional dengan membawa kehadapan pengadilan dan diadili secara adil. Karena pelaku yang dikejar adalah orang dengan kewarganegaraan yang bisa saja bukan merupakan negara peserta, maka pemberlakuan ketentuan ini tidak lagi sesuai dengan asas pacta sunt servanda tetapi terikatnya negara ketiga karena kejahatan tersebut merupakan kejahatan internasional yang sudah diakui dalam hukum kebiasaan internasional.

\section{UCAPAN TERIMA KASIH}

Puji Syukur kepada Tuhan Yang Maha Kuasa penulisan artikel ini telah diselesaikan dengan baik. Terima kasih kepada Sekolah Tinggi Bahasa Asing Prayoga (STBA Prayoga) yang telah memberikan dukungan kepada penulis dalam melaksanakan peneletian serta menyelesaikan penulisan artikel ini.

\section{DAFTAR PUSTAKA}

Adolf, H. 2006, Dasar-dasar Hukum Kontrak Internasional, Refika Aditama, Bandung. 
Danel Aditia Situngkir: Asas Pacta Sunt Servanda Dalam Penegakan Hukum Pidana...

Amiruddin. 2012. Pengantar Metode Penelitian Hukum, PT. Raja Grafindo Persada, Jakarta.

Ardhiwisastra, Y. B. 2003. Hukum Internasional, PT. Alumni, Bandung.

Ardhwisastra, Y. B. 1999. Imunitas Kedaulatan Negara di Forum Pengadilan Asing, PT. Penerbit, Bandung.

Atmasasmita, R. 2006. Pengantar Hukum Pidana Internasional, Refika Aditama, Bandung.

Benzing, M. 2003. The Complementarity Regime of the International Criminal Court: International Criminal Justice between State Sovereignty and the Fight against Impunity, Max Planck Yearbook a/United Nations Law, Volume 7.

Convention, V. 1969. UN. Retrieved Februari 27, 2018, from legal.un.org: http://legal.un.org/ilc/texts/instrume nts/english/conventions/1_1_1969.p $\mathrm{df}$

Fitzmaurice, M. 2002. Third Parties and the Law of Treaties. Netherlands: Max Planck Yearbook, Volume 6, Kluwer Law International.

ICRC. 1964. Treaties, States Parties and Commentaries.

International Military Tribunal For The Far East. 1948.
Iskandar, J. T. 2009. Hukum Internasional Kontemporer, Refika Aditama, Bandung.

Marzuki, P. M, 2005, Penelitian Hukum, Prenada Media Grup, Jakarta.

Nations, U. 1945. Charter of The United Nations, United Nations, San Fransisco.

Nations, U. Universal Declaration of Human Rights.

Parthiana, I. W. 2006. Hukum Pidana Internasional, CV. Yrama Widya, Bandung.

Peter Mahmud Marzuki, 2. P.

Situngkir, D. A. 2013. Yurisdiksi Mahkamah Pidana Internasional (International Criminal Court) Terhadap Negara Bukan Peserta Statuta Roma, Program Pascasarjana Fakultas Hukum Universitas Andalas, Padang.

Statute of The International Criminal Tribunal For The Former Yugoslavia. 1993.

Statute Of The International Tribunal For Rwanda. 1994.

Statute, R. 1998. Rome Statute of International Criminal Court.

The Charter and Judgment of the Nürnberg Tribunal-History and Analysis. 1949. New York.

The Geneva Conventions of 12 August 1949. 1949. Geneva: International Committe of Red Cross. 